\title{
THE EFFECTIVENESS OF PHYTASE IN BROILER DIETS IN IMPROVING PRODUCTION PERFORMANCES AND BONE FEATURES
}

\author{
ŽIVKOV-BALOŠ MILICA, KOVAČEVIĆ MIRA, MIHALJEV Ž, STOJANOV I, KAPETANOV M, \\ STOJANOVIĆ DRAGICA and PETROVIĆ JELENA
}

Scientific Veterinary Institute "Novi Sad", Novi Sad

(Received 21st September 2011)

The possibilities of use of microbial phytase in maize/soybean meal diets for broilers from 21 to 42 days of age with different dietary total and available phosphorus (TP and AP) levels were investigated. A 22-day experiment was carried out on 240 Arbor Acres broilers of both sexes divided into six groups. The broilers were given diets with $0.43 \%$, $0.23 \%$ or $0.10 \% A P$, with or without phytase supplementation. During the experiment, health status and mortality, physical, chemical and morphological bone characteristics were investigated. Reduction of the mineral source of $P$ from the diet increased mortality and health problems. Addition of phytase decreased mortality and alleviated negative effects of dicalcium phosphate exclusion. Histological, physical and chemical analysis of broiler tibia indicates that the extent and significance of changes depend on $P$ deficiency and phytase addition. Phytase efficacy was greater in diets with a reduced level of dicalcium phosphate.

Key words: broilers, phytase, production performances, tibia

\section{INTRODUCTION}

The needs of phosphorus $(\mathrm{P})$ in poultry diet presents a tremendous problem. A considerable number of studies has been carried out in the field of poultry nutrition in order to specify these needs. Several factors affect $P$ needs in broilers. The most important is the composition of the feed mix, the environment, production management, and climate (Rama Rao et al., 1999). The level of phosphorus in the diet, higher or lower than the optimal, can effects the health and production performance of broilers.

The optimal concentration of phosphorus in poultry diet primarily depends on the management conditions and ways of regulating the environmental pollution problem. Excess phosphorus in the diet reduces the availability of the other divalent cation of phytase phosphorus, so the waste from poultry farms is a rich source of nitrogen and phosphorus, and therefore presents a significant pollutant of the environment (Toor et al., 2009). The problem is even more complicated by the increasing trend of using vegetable proteins, that contain 
large amounts of phytate phosphorus (Rama Rao et al., 1999). Given the role in energy metabolism (ATP, ADP), phosphorus deficiency in metabolically active tissues causes reduction of intermediary metabolism and synthesis of nucleic acids, or metabolic activity of cells (Kuznetsov et al., 1987). Pronounced long-term deficit causes irregular ossification, structural deformities of bones and occurrence of soft and brittle bones in young (rickets) and adult animals (osteomyelitis), especially in intensive production. The process of bone demineralization (osteoporosis) may be associated with the replacement of bone fibrous tissue (fibrous osteodystrophy). In birds, mineralization disorders caused by phosphorus deficiency relates to the change in the length of $\mathrm{DHZ}$ or metaphyseal primary spongiosa (Jandå and Dickson, 1980, Long et al., 1984, Ewing et al., 1995) and low penetration of metaphyseal blood vessels (Wise, 1975) .

For young broilers it is more important to provide an adequate amount of phosphorus, because more than the adult birds they use phosphorus of low availability, or phosphorus phytine salt, which is due to lower endogenous activity of intestinal phytase. The level of endogenous phytase activity highly correlates to the body mass of chickens (Shakouri et al., 2009). Intestinal phytase activity on the surface of small-bowel mucosa villi in laying hens and broilers is 5.2, and $3.8 \mathrm{mmol} \mathrm{P} / \mathrm{min}$, respectively (Maenz and Classen, 1998). Edens et al. (1999) point on the ability of older broilers to use phytine phosphorus by adapting the digestive tract and increasing the activity of intestinal phytase. Similar views have other authors (Edwards, 1993; Van der Klis et al., 1997) who report that the digestibility of phosphorus phytase increases from $31 \%$ at the age of 14 days to $38.2 \%$ at the age of 25 days.

In commercial poultry production, target animals are broilers from 21 days until they reach slaughter weight. This is the period when modern hybrid broilers consume about $70-80 \%$ of the anticipated amount of fattening feed, hence at this period the most positive effects of phytase can be observed and registered.

Nelson (1967) and Nelson et al. (1968) were among the first who reported positive effects of adding microbial phytase to the meal. Body weight gain in broilers fed the diet without mineral premix, but given a phytase supplement, was as good as the group of broilers whose diets used dicalcium phosphate as a source of phosphorus. Farrell et al. (1993) examined the effect of microbial phytase on $\mathrm{P}$ release from mixtures composed of sorghum and soybean meal and achieved satisfactory performance related to the standard diet with dicalcium phosphate.

In trials carried out on broilers 24, i.e. 28 days old, Simons et al. (1990) confirmed a positive effect of phytase on growth performance, feed conversion, availability and reduced amount of phosphorus excreted. Harter-Dennis et al. (2001) confirmed that reducing the available phosphorus from $0.35 \%$ to $0.15 \%$ in broiler diet based on corn/soybean meal caused a significant decrease in body weight gain and poor feed conversion, while the use of phytase improved body weight gain and reduced conversion. The authors report that the use of mixtures with different concentrations of AP $(0.15$ to $0.35 \%$ without phytase; $0.15 \%$ with phytase) in the diet for broilers aged 21-42 days, the tibia breaking force and ash 
content increased linearly in proportion to the content of AP from $24.21 \mathrm{~kg}$ to 40.53 $\mathrm{kg}$, and from $45.46 \%$ to $53.51 \%$. Supplementing phytase increases the breaking force to $31.17 \mathrm{~kg}$, and tibia ash content to $49.18 \%$. Based on these results the authors believe that the enzyme Allzyme Phytase "saves" AP from 0.05 to $0.075 \%$.

The aim of this paper is to point out the possibilities and benefits of phytase supplement in broiler diets, with a special emphasis on the degree of mineralization.

\section{MATERIAL AND METHODS}

Animals. The experiment was performed on 240, 21 day old, Arbor Acres chickens of both sexes, originating from the same parental flock. The broilers were individually labeled by wing-marks. Preventive measures, housing, management, feeding and watering conditions during the experiment were adapted to the ground floor breeding system. Throughout the investigation period the technological conditions were in accordance with the normatives prescribed for this provenience (Arbor Acres Farm, 1997).

Diets. The broilers were divided into 6 groups. Ratio and quantitative share of the feedstuff in feed mixes for experimental broilers was formulated in accordance with different stages of fattening (NCR, 1994). The nutritive matter content in the diets was adjusted to the needs of broilers - starter feed II (from day 21 to 35), i.e. feed mix for the final fattening feed II (from day 35 to 42). The control group $(\mathrm{C}$ and $\mathrm{C}+)$ of broilers was fed the standard diet.

The content of TP and AP in the diet for the experimental groups was regulated by reducing the concentration of dicalcium phosphate (E-I and $\mathrm{E}-\mathrm{I}+$ ), except the diet for the broilers in the second experimental group (E-II and $\mathrm{E}-\mathrm{II}+$ ) where the total amount of phosphorus comes from raw materials. The diet for the experimental groups $(\mathrm{C}+, \mathrm{E}-\mathrm{I}+$ and $\mathrm{E}-\mathrm{II}+)$ was supplemented with "Allzyme Phytase" (supplier: "Alltech", USA). The enzyme is of microbial origin, obtained as fermentation extract of a genetically unmodified strain of Aspergillus niger.

Experimental procedure. The experimental broilers had free access to water and diet (ad libitum). Preventive measures were applied, and all investigated broilers were subjected to permanent veterinary control, and all health status changes were monitored and recorded. Control measurements of body mass of broilers were performed at the beginning and at the end of the experiment using a technical scale with accuracy rate $10^{-3} \mathrm{~kg}$.

Feedstuff samples for microbiological and chemical assaying were collected immediately before the onset of the experiment, as well as throughout the investigation period. At the $35^{\text {th }}$ day of the experiment, as well as at the end of the experiment (day 42) ten broilers from each group of both sexes were sacrificed (with equal sex ratio) and bone samples collected (left and right tibia) for further investigation. Immediately after sacrificing the right tibia samples were prepared for histological analysis. Left tibia samples were frozen in plastic bags for mechanical and chemical analysis. 
Table 1. Composition (\%) of broiler grower diets; 21-35 days of age

\begin{tabular}{|l|c|c|c|c|c|c|}
\hline \multirow{2}{*}{ Feedstuffs, \% } & \multicolumn{6}{|c|}{ Group } \\
\cline { 2 - 7 } & C & C+ & E-I & E-I+ & E-II & E-II+ \\
\hline \hline Maize & 58.3 & 58.3 & 58.8 & 58.8 & 59.0 & 59.0 \\
\hline Soybean meal & 26.2 & 26.2 & 26.2 & 26.2 & 26.2 & 26.2 \\
\hline Sunflower meal & 4.0 & 4.0 & 4.0 & 4.0 & 4.0 & 4.0 \\
\hline Yeast & 2.0 & 2.0 & 2.0 & 2.0 & 2.0 & 2.0 \\
\hline Vegetable oil & 5.2 & 5.2 & 5.2 & 5.2 & 5.2 & 5.2 \\
\hline DL Methionine & 0.2 & 0.2 & 0.2 & 0.2 & 0.2 & 0.2 \\
\hline Limestone & 0.7 & 0.7 & 1.5 & 1.5 & 2.1 & 2.1 \\
\hline Dicalcium phosphate & 2.1 & 2.1 & 0.8 & 0.8 & - & - \\
\hline Salt & 0.3 & 0.3 & 0.3 & 0.3 & 0.3 & 0.3 \\
\hline Mineral-vitamin mixture & 1.0 & 1.0 & 1.0 & 1.0 & 1.0 & 1.0 \\
\hline Phytase, 250 PU/kg & - & + & - & + & - & + \\
\hline \hline \multicolumn{1}{|c|}{$\Sigma$} & 100 & 100 & 100 & 100 & 100 & 100 \\
\hline
\end{tabular}

Table 2. Composition (\%) broiler finisher diets; 35-42 days of age

\begin{tabular}{|l|c|c|c|c|c|c|}
\hline \multirow{2}{*}{ Feedstuffs, \% } & \multicolumn{6}{|c|}{ Group } \\
\cline { 2 - 7 } & C & C+ & E-I & E-I+ & E-II & E-II+ \\
\hline \hline Maize & 62.2 & 62.2 & 62.7 & 62.7 & 62.9 & 62.9 \\
\hline Soybean meal & 21.8 & 21.8 & 21.8 & 21.8 & 21.8 & 21.8 \\
\hline Sunflower meal & 5.0 & 5.0 & 5.0 & 5.0 & 5.0 & 5.0 \\
\hline Yeast & 2.0 & 2.0 & 2.0 & 2.0 & 2.0 & 2.0 \\
\hline Vegetable oil & 4.8 & 4.8 & 4.8 & 4.8 & 4.8 & 4.8 \\
\hline DL Methionine & 0.2 & 0.2 & 0.2 & 0.2 & 0.2 & 0.2 \\
\hline Limestone & 0.6 & 0.6 & 1.4 & 1.4 & 2.0 & 2.0 \\
\hline Dicalcium phosphate & 2.1 & 2.1 & 0.8 & 0.8 & - & - \\
\hline Salt & 0.3 & 0.3 & 0.3 & 0.3 & 0.3 & 0.3 \\
\hline Mineral-vitamin mixture & 1.0 & 1.0 & 1.0 & 1.0 & 1.0 & 1.0 \\
\hline Phytase, 250 PU/kg & - & + & - & + & - & + \\
\hline \hline \multicolumn{1}{|c|}{$\Sigma$} & 100 & 100 & 100 & 100 & 100 & 100 \\
\hline
\end{tabular}

Method of analysis. The basic chemical composition of the feedstuff was determined using standard methods (Pravilnik, 1987). Feed and bone samples were dried and examined for mineral matter content (SRPS EN ISO 6869:2008). All samples were analyzed for phosphorus content by the use of 
spectrophotometry, whereas the phytate-P content was determined by the method of Haug and Lantzsch (1983). Calcium concentration was analyzed using flame emission spectrophotometry on Varian SpectrAA10.

After thawing the left tibia samples, soft tissues were completely removed. Subsequently, the bone strength was determined by applying the modified method of mechanical breakage using IPNIS-apparatus (Mašić et al., 1985). For ash determination, $\mathrm{Ca}$ and $\mathrm{P}$ content the bones were cleaned and defatted by cooking and mechanical removal of muscular tissues and ligaments, and then dried to a constant weight at $105^{\circ} \mathrm{C}$.

Samples of the growth plate of the right tibia, about $5 \mathrm{~mm}$ in length, were carefully taken by costotomy and decalcified with $10 \%$ EDTA. Decalcified samples were fixed in $10 \%$ neutral formalin and absolute alcohol and embedded in paraffin using standard techniques. Tissue sections, 5-8 $\mu \mathrm{m}$ thick, were stained by standard HE method (Scheuer and Chalk, 1988). Microphotographs of histology preparations were performed on OLYMPUS BX 40. The same microscope was used for morphometric examination, i.e. determination of the calcification zone length in the tibia using a linear ocular micrometer.

Statistical analysis. The obtained results were grouped into corresponding statistical series and subjected to standard ANOVA procedure using the software package SPSS 8.0 for Windows.

\section{RESULTS AND DISCUSSION}

Chemical analyses confirmed that the well-balanced $\mathrm{P}$ content in the feed mixes for the control groups at $21-35$ days were $0.80 \%$ for the total and $0.46 \%$ for AP. Chemical composition of diets for the control group at $35-42$ days was $0.70 \%$ for TP and $0.43 \%$ for AP. Basic chemical composition of broiler feed did not differ from the control mix, except the concentration of phosphorus. Decrease of the TP and AP in feed mixes to the level of $0.42 \%(0.44 \%)$ and $0.09 \%(0.10 \%)$ respectively, was accomplished by reducing or excluding dicalcium phosphate. The concentration of phytate-phosphorus, as well as calcium content was the same in all mixes. In comparison to the control group, the concentrations of TP was lower by $30.38-45.57 \%$, and the concentration of AP was lower by 46.51 $79.08 \%$. Relative proportion of phytate phosphorus in the TP content ranged from $31.6 \%$ in diets fed to control groups to $61.90 \%$ in diets fed to experimental groups. The obtained results support the available literature data that more than $60 \%$ of $P$ contained in poultry diets is present as phytate-phosphorus (Harland and Morris, 1995; Kornegay, 1999; Jognbloed et al., 2000). Feed mixtures based on maize and soybean pellets mostly contain 8.0 to $9.0 \mathrm{~g} / \mathrm{kg}$ phytic acid, i.e. 2.2 to $2.5 \mathrm{~g} / \mathrm{kg}$ phytate (Cabahug et al., 1999). Phytate content, degradated under phytase, reduces the need for phosphorus by 1.0 to $1.2 \mathrm{~g} / \mathrm{kg}$ in broiler mix (Yi et al., 1996). Ravindran et al. (2001) detected that the digestibility of phytate in meals, not supplemented with phytase was $28 \%$, while by supplementing with phytase digestibility increased for more than $50 \%$. Using phytase in broiler mix increased AP for more than 60\% (Simons et al., 1990; Schwarz and Hoppe, 1992; Huyghebaert, 1997). Based on the aforementioned results it can be concluded 
that the applied phytase content is adequate and corresponds to the mixes based on wheat and soybean meal with a low concentration of $\mathrm{P}$ of mineral origin.

Most producers recommend supplementation with 250-100 PU/kg in broiler diet, where $\mathrm{P}$ concentration may be reduced, depending on the level of phytase, TP and AP in the meal. Adding phytase in the recommended concentration increases AP, and $800 \mathrm{PU}$ phytase/kg can be replaced with $0.1 \%$ phosphorus, without no consequences on production results (Vogt, 1992).

Table 3. Chemical composition (\%) of broiler grower diets; 21 to 35 days of age

\begin{tabular}{|l|r|r|r|r|r|r|}
\hline \multicolumn{7}{|c|}{ Group } \\
\hline Analysed values & \multicolumn{1}{c|}{ C } & \multicolumn{1}{c|}{ C +} & \multicolumn{1}{c|}{ E-I } & \multicolumn{1}{c|}{ E-I+ } & \multicolumn{1}{c|}{ E-II } & E-II+ \\
\hline \hline Crude protein, \% & 20.40 & 20.25 & 20.50 & 19.95 & 20.10 & 20.00 \\
\hline Crude fat, \% & 6.55 & 6.33 & 6.41 & 6.42 & 6.50 & 6.12 \\
\hline Crude fiber, \% & 4.32 & 4.43 & 4.41 & 4.53 & 4.66 & 4.08 \\
\hline ME, MJ/kg & 13.39 & 13.39 & 13.45 & 13.40 & 13.37 & 13.32 \\
\hline Lysine, \% & 1.08 & 1.07 & 1.12 & 1.07 & 1.10 & 1.09 \\
\hline Methionine+cystine, \% & 0.82 & 0.83 & 0.89 & 0.84 & 0.82 & 0.81 \\
\hline Triptophan, \% & 0.25 & 0.27 & 0.25 & 0.25 & 0.23 & 0.28 \\
\hline Calcium, \% & 1.15 & 1.09 & 1.10 & 1.05 & 1.01 & 1.10 \\
\hline Phosphorus, total, \% & 0.79 & 0.78 & 0.56 & 0.55 & 0.42 & 0.43 \\
\hline Phosphorus, available, \% & 0.43 & 0.43 & 0.23 & 0.22 & 0.09 & 0.10 \\
\hline Phosphorus, phytine, \% & 0.26 & 0.25 & 0.24 & 0.24 & 0.25 & 0.26 \\
\hline Manganese, mg/kg & 104.30 & 111.33 & 102.50 & 100.07 & 98.43 & 108.87 \\
\hline Zinc, mg/kg & 74.77 & 71.43 & 70.97 & 64.73 & 69.90 & 78.23 \\
\hline Copper, mg/kg & 15.48 & 12.60 & 12.58 & 18.12 & 14.28 & 18.22 \\
\hline Iron, mg/kg & 148.38 & 152.55 & 147.32 & 160.00 & 142.02 & 150.04 \\
\hline
\end{tabular}

Body mass range and average daily weight gain of broilers in the experiment are shown in Table 3. Body mass of broilers and average daily gain of the control group $(C)$ were within the margins of technological normatives for Arbor Acres provenience. It is to be emphasized that values of the cited parameters were somewhat higher in the broilers fed with diets containing the recommended dietary allowance for phosphorus. Body mass of the broilers in $\mathrm{C}+$ group on the $35^{\text {th }}$ day was significantly higher compared to body mass of broilers in group $C(p<0.05)$. Reduction of phosphorus content in diets for experimental groups resulted in corresponding reduction of body mass and daily weight gain. Differences among groups were highly significant $(p<0.01)$. Supplementation of phytase to low-phosphorus diets substantially increased body mass and daily weight gain in the corresponding group $(p<0.01)$. However, the effect was not sufficient to reach the corresponding parameter values in the control group. 
Similar values for body mass in broilers fed diets containing approximately the same calcium and phosphorus concentrations and phytase supplement are reported by Simons and Versteegh (1993), Cabahug et al. (1999), Ahmad et al. (2000), Ravindran et al. (2001), Mulyantini et al. (2004), Vohra et al. (2006), Timmons et al. (2008) and Shakouri et al. (2009).

Table 4. Chemical composition (\%) of broiler finisher diets; 35 to 42 days of age

\begin{tabular}{|l|r|r|r|r|r|r|}
\hline \multicolumn{2}{|c|}{} & \multicolumn{5}{|c|}{ Group } \\
\hline Analysed values & \multicolumn{1}{c|}{ C } & \multicolumn{1}{c|}{ C+ } & \multicolumn{1}{c|}{ E-I } & E-I+ & E-II & E-II+ \\
\hline Crude protein, \% & 18.50 & 18.70 & 18.50 & 18.20 & 18.25 & 18.55 \\
\hline Crude fat, \% & 6.67 & 6.57 & 6.28 & 6.16 & 6.09 & 6.64 \\
\hline Crude fiber, \% & 4.51 & 4.48 & 4.57 & 4.33 & 4.51 & 4.74 \\
\hline ME, MJ/kg & 13.36 & 13.30 & 13.12 & 13.25 & 13.36 & 13.36 \\
\hline Lysine, \% & 0.96 & 0.96 & 0.97 & 0.97 & 0.97 & 0.96 \\
\hline Methionine+cystine, \% & 0.77 & 0.77 & 0.78 & 0.77 & 0.77 & 0.79 \\
\hline Triptophan, \% & 0.22 & 0.23 & 0.22 & 0.24 & 0.23 & 0.23 \\
\hline Calcium, \% & 0.88 & 0.91 & 0.89 & 0.92 & 0.88 & 0.90 \\
\hline Phosphorus, total, \% & 0.70 & 0.74 & 0.56 & 0.57 & 0.46 & 0.44 \\
\hline Phosphorus, available, \% & 0.43 & 0.44 & 0.22 & 0.25 & 0.10 & 0.12 \\
\hline Phosphorus, phytine, \% & 0.25 & 0.27 & 0.27 & 0.26 & 0.26 & 0.26 \\
\hline Manganese, mg/kg & 102.50 & 108.57 & 99.97 & 104.57 & 100.03 & 100.97 \\
\hline Zinc,mg/kg & 68.90 & 75.92 & 77.76 & 66.56 & 71.45 & 78.55 \\
\hline Copper, mg/kg & 13.77 & 16.53 & 15.68 & 16.60 & 16.33 & 18.65 \\
\hline Iron, mg/kg & 174.00 & 170.50 & 156.33 & 154.67 & 144.33 & 131.33 \\
\hline
\end{tabular}

Examination of the mineralization rate indicators, such as bone strength, ash content and calcium and phosphorus concentration in the tibia of experimental broilers revealed substantial differences among investigated groups (Table 4). Bone density in the control broilers corresponds to age and increases with time. A clearly pronounced negative effect on tibia strength was recorded in diets with decreased level of TP and AP. Similarly to previous groups, tibia strength increased with time, but in comparison to the control group it was significantly reduced. Supplementation of phytase to the diet with decreased concentration of the TP and AP exhibited some positive effects. Denbow et al. (1998) reported similar results which points that the increase of AP concentration, as well as the presence of enzyme, has positive effects on tibia breaking force. Similar conclusions were reached by Richter (1993), Denbow et al. (1995), Qian et al. (1996), Pillai et al. (2006), Venäläinen et al. (2006), as well as Jiang et al. (2009). 
Table 5. Body mass and average daily weight gain $\left({ }^{*}\right)$ throughout the investigation period

\begin{tabular}{|c|c|c|c|c|c|}
\hline \multirow{3}{*}{ Group } & \multicolumn{2}{|c|}{ Body mass, $\mathrm{g}$} & \multicolumn{3}{|c|}{ Daily weight gain, g } \\
\hline & \multicolumn{2}{|c|}{ Day } & \multicolumn{3}{|c|}{ Investigation period (days) } \\
\hline & 35. & 42. & 21-35. & $35-42$. & $1-42$ \\
\hline $\mathrm{C}$ & $1624.0 \pm 173.6^{a, x}$ & $2216.1 \pm 268.6^{x}$ & $63.68 \pm 8.94 a, x$ & $82.47 \pm 17.17^{x}$ & $51.11 \pm 6.42^{x}$ \\
\hline $\mathrm{C}+$ & $1725.9 \pm 249.9^{b, x}$ & $2259.5 \pm 313.0^{x}$ & $70.26 \pm 11.75^{x}$ & $83.95 \pm 21.13^{x}$ & $54.10 \pm 7.33^{x}$ \\
\hline E-I & $1324.8 \pm 166.4 y$ & $1865.0 \pm 234.0 y$ & $55.42 \pm 8.40^{\mathrm{b}, \mathrm{y}}$ & $78.56 \pm 10.15^{x}$ & $43.51 \pm 5.56 y$ \\
\hline $\mathrm{E}-\mathrm{I}+$ & $1444.6 \pm 174.6^{z}$ & $1973.7 \pm 246.8 y$ & $59.94 \pm 8.56 c, y$ & $76.45 \pm 15.69^{x}$ & $46.11 \pm 5.87 y$ \\
\hline E-II & $827.5 \pm 204.3^{w}$ & $1282.2 \pm 259.2^{z}$ & $35.00 \pm 11.03^{w}$ & $51.45 \pm 20.75 y$ & $29.65 \pm 6.20^{2}$ \\
\hline E-II+ & $964.4 \pm 209.39$ & $1388.6 \pm 295.0^{w}$ & $28.90 \pm 14.67^{z}$ & $48.40 \pm 15.99 y$ & $32.18 \pm 7.01^{z}$ \\
\hline
\end{tabular}

*Values expressed as $\bar{X} \pm S D$; ${ }^{a, b} p<0.05 ; x, y, z, w, q p<0.01$

Tibia strength in the broiler group fed a diet without inorganic phosphorus were highly statistically significant to significantly lower compared to both previous groups. Harter-Denis et al. $(2000,2001)$ reported that reduction of the content of AP from $0.45 \%$ to $0.25 \%$ in the starter diet significantly reduced the bone breaking force up to $72.2 \%(11.5$ to $3.20 \mathrm{~kg})$. Phytase supplementation increased the bone breaking force from 3.2 to $4.9 \mathrm{~kg}$. Using the diet with different concentrations of AP in the diet for broilers at 21-42 days of age, bone breaking forces linearly increases from $24.21 \mathrm{~kg}$ to $40.53 \mathrm{~kg}$, proportional to the AP content.

Ash content, phosphorus and calcium concentration in the tibia of experimental broilers increase proportionally with the age, which is in accordance to the reports of Dukes (1975) and Lukić (2001). Phytase efficacy, in the sense of increased content of ash, phosphorus and calcium in the tibia is increased in diets with reduced concentration of AP, and is slightly lower when lacking a mineral source of phosphorus. At the end of the investigation period (day 42) the highest ash, phosphorus an calcium content in the tibia was noticed in group $\mathrm{C}+(0.74 \%$ of TP and $0.44 \%$ of AP), although the differences were not statistically significant. Ash content, phosphorus and calcium concentration in the tibia of broilers fed the diet with lower $\mathrm{P}$ concentration $(0.57 \%$ TP and $0.25 \%$ AP) was not statistically different from group C $(0.74 \%$ TP and $0.44 \%$ AP), which is in accordance to the results of Ahmad et al. (2000), Ravindran et al. (2001) and Harter-Dennis et al. (2000, 2001). Besides explicit positive effects, it may be concluded that phytase supplementation was not able to compensate the lack of TP and AP in diets.

Histological findings in the proximal tibia of broilers in the control group (C and $\mathrm{C}+$ ) did not differ revealing normal histological morphology (Figures 1a, 1b, $2 \mathrm{a}$ and $2 \mathrm{~b}$ ). Differences in the length of DH and MPS zones (Table 5) were not statistically significant. 
Acta Veterinaria (Beograd), Vol. 62, No. 2-3, 297-311, 2012.

Živković-Baloš Milica et al.: The effectiveness of phytase in broiler

diets in improving production performances and bone features

Table 6. Breaking force of tibia and the content of ash, calcium and phosphorus in the tibia of experimental broilers

\begin{tabular}{|c|c|c|c|c|}
\hline \multirow[t]{2}{*}{ Group } & \begin{tabular}{|c|} 
Breaking force, \\
$\mathrm{kg}$
\end{tabular} & \begin{tabular}{|c|} 
Content of ash, \\
$\%$
\end{tabular} & $\begin{array}{c}\text { Content of calcium, } \\
\%\end{array}$ & $\begin{array}{c}\text { Content of phosphorus, } \\
\%\end{array}$ \\
\hline & \multicolumn{4}{|c|}{ 35. day } \\
\hline C & $28.36 \pm 4.65^{a, x}$ & $56.46 \pm 4.70^{x}$ & $21.18 \pm 2.96^{x}$ & $9.47 \pm 0.71^{x}$ \\
\hline $\mathrm{C}+$ & $33.38 \pm 6.05^{b, x}$ & $55.40 \pm 3.24 x$ & $21.37 \pm 4.35^{x}$ & $9.67 \pm 1.43^{a, x}$ \\
\hline E-I & $22.41 \pm 4.31^{c, y}$ & $45.30 \pm 4.16^{a, y}$ & $14.86 \pm 4.00 y$ & $7.56 \pm 0.81^{b, x}$ \\
\hline $\mathrm{E}-\mathrm{I}+$ & $27.47 \pm 6.62^{a, y}$ & $50.08 \pm 3.73^{b, y}$ & $19.12 \pm 2.20 z$ & $8.02 \pm 0.49 b, x$ \\
\hline E-II & $9.36 \pm 1.90^{z}$ & $37.36 \pm 6.61^{b, z}$ & $12.64 \pm 1.78 \mathrm{y}$ & $6.14 \pm 0.85 y$ \\
\hline \multirow[t]{2}{*}{$\mathrm{E}-\mathrm{II}+$} & $11.50 \pm 3.06^{z}$ & $41.10 \pm 2.56^{b, z}$ & $13.01 \pm 1.94 y$ & $6.76 \pm 0.51^{y}$ \\
\hline & \multicolumn{4}{|c|}{ 42. day } \\
\hline $\mathrm{C}$ & $35.71 \pm 7.66^{a, x}$ & $59.90 \pm 4.35^{x}$ & $21.01 \pm 2.38^{x}$ & $10.14 \pm 0.69^{x}$ \\
\hline $\mathrm{C}+$ & $38.25 \pm 8.13^{x}$ & $60.88 \pm 2.86^{x}$ & $22.15 \pm 1.71 a, x$ & $10.44 \pm 0.49 a, x$ \\
\hline E-I & $38.87 \pm 8.10^{x}$ & $58.52 \pm 5.30^{x}$ & $19.86 \pm 1.81^{b, x}$ & $9.71 \pm 1.35^{b, x}$ \\
\hline $\mathrm{E}-\mathrm{I}+$ & $42.94 \pm 11.97 b, x$ & $61.18 \pm 7.32^{x}$ & $20.92 \pm 2.87 x$ & $9.50 \pm 0.95^{b, x}$ \\
\hline E-II & $17.60 \pm 3.55 y$ & $47.93 \pm 3.29 y$ & $13.04 \pm 0.46 y$ & $7.78 \pm 0.45 y$ \\
\hline E-II+ & $19.22 \pm 4.94 y$ & $45.20 \pm 3.79 y$ & $14.06 \pm 2.61 y$ & $7.59 \pm 0.61 y$ \\
\hline
\end{tabular}

*Values expressed as $\overline{\mathrm{X}} \pm \mathrm{SD} ; \quad$ a,b $\mathrm{p}<0.05 ; \quad \mathrm{x}, \mathrm{y}, \mathrm{z}, \mathrm{w} \mathrm{p}<0.01$

Table 7. Length of degenerated hypertrophic zone of tibia (DHZ), [ $\mu \mathrm{m}]$

\begin{tabular}{|c|c|c|}
\hline \multirow{2}{*}{ Group } & \multicolumn{2}{|c|}{ Length of degenerated hypertrophic zone $(\mathrm{DHZ}),[\mu \mathrm{m}]$} \\
\cline { 2 - 3 } & 35. day & 42. day \\
\hline \hline C & $41.86 \pm 2.74^{\mathrm{a}}$ & $38.49 \pm 1.92^{\mathrm{a}, \mathrm{x}}$ \\
\hline $\mathrm{C}+$ & $37.79 \pm 2.61^{\mathrm{a}, \mathrm{x}}$ & $36.19 \pm 1.98^{\mathrm{x}}$ \\
\hline E-I & $93.10 \pm 6.24^{\mathrm{b}, \mathrm{y}}$ & $71.86 \pm 5.96^{\mathrm{b}, \mathrm{y}}$ \\
\hline E-I+ & $52.74 \pm 3.76^{\mathrm{c}}$ & $51.23 \pm 2.52^{\mathrm{c}, \mathrm{z}}$ \\
\hline E-II & $139.09 \pm 7.37^{\mathrm{d}, \mathrm{w}}$ & $79.14 \pm 7.06 \mathrm{y}$ \\
\hline E-II+ & $121.86 \pm 14.10^{\mathrm{e}, \mathrm{q}}$ & $75.32 \pm 5.19 \mathrm{y}$ \\
\hline
\end{tabular}

*Values expressed as $\bar{X} \pm S D ;{ }^{a, b} p<0.05 ; x, y, z, w, q p<0.01$

In the 35-days-old broilers in groups $\mathrm{C}$ and $\mathrm{C}+$ (Fig. $1 \mathrm{a}$ and $1 \mathrm{~b}$ ) a decrease in $\mathrm{DH}$ zone and increase in length of secondary spongiosa (MSS) was noticed, while in the same groups in 42-day-old broilers an increase of secondary spongiosa was observed. The differences in $\mathrm{DH}$ zone length were also highly statistically significant (Table 5) on days 35 and 42 of the experiment. In broilers aged 35 days from groups $\mathrm{O}-\mathrm{I}$ and $\mathrm{O}-\mathrm{Il}$ cartilage columns in $\mathrm{DHZ}$ were longer comparing to the control group (Fig. 1c and 1e). Besides, in the group O-II 
epiphyseal blood vessels were located in the hypertrophic zone $(\mathrm{HZ})$ and cause deviation in this part of the bone. The differences in the length of $\mathrm{DHZ}$ are statistically significant.
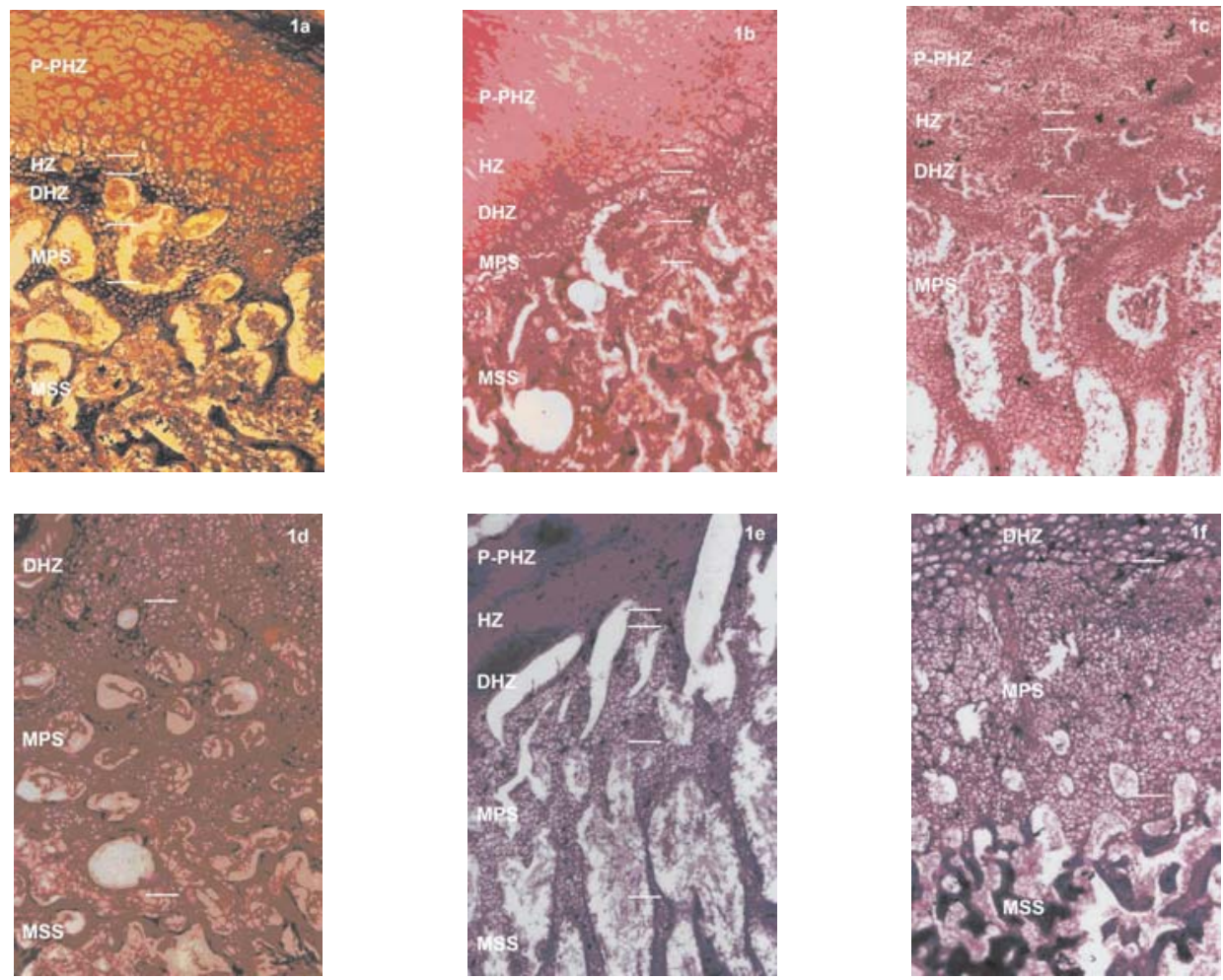

Fig. 1a-f. Microphotographs of proximal part of tibia of 35 days old broilers. H\&E 100x $\mathrm{P}-\mathrm{PHZ}$ - proliferating-prehypertrophied zone, HZ - hypertrophied zone, DHZ degenerating hypertrophied zone, MPS - metaphyseal primary spongiosa, MSS metaphyseal secondary spongiosa

1a-b) C and C+ group, revealed normal histological morphology, 1c-d) E-I and E-I+ group, note lengthened DHZ and MPS, 1e-f) E-II and E-II+ group, there is a lengthening of MPS and MSS

Histological findings in the proximal tibia of broilers from the experimental group E-I at the age of 42 days was featured by shorter MSS and longer MPS zone compared to the control group. The junction of the metaphyseal primary spongiosa (MPS) to metaphyseal secondary spongiosa (MSS) in these experimental groups was stepped and discontinuous (Fig. 2c and 2e), but osteoblasts and osteocytes were smaller and less numerous. In both age groups of broilers in E-I+ a reduced DHZ and MPS was observed (Fig 1d and 2d) and statistically significant differences in the length of $\mathrm{DHZ}$. Changes on the bones in 
Zivković-Baloš Milica et al.: The effectiveness of phytase in broiler

diets in improving production performances and bone features

broilers from group E-II+ are distinct and the changes correspond to changes observed in group E-II.

The most recognized histological changes in the bone growth zone of the experimental group that was fed with a low phosphorus diet (E-I) or was totally withheld (E-II) was the increase of the length of $\mathrm{DHZ}$ and metaphyseal primary spongiosa (MPS), whereas the metaphyseal secondary spongiosa (MSS) consisted mostly of osteoid tissue. These findings conform to reports of other authors (Lacey and Huffer, 1982; Long et al., 1984; Quian et al., 1996) acknowledging that specified changes are typical for the histological picture of rickets induced by phosphorus deficiency in the body. Moreover, it is obvious that the size and severity of lesions strongly correlate with the rate of phosphorus deficit in the diet, as well as with the supplementation or lack of phytase.
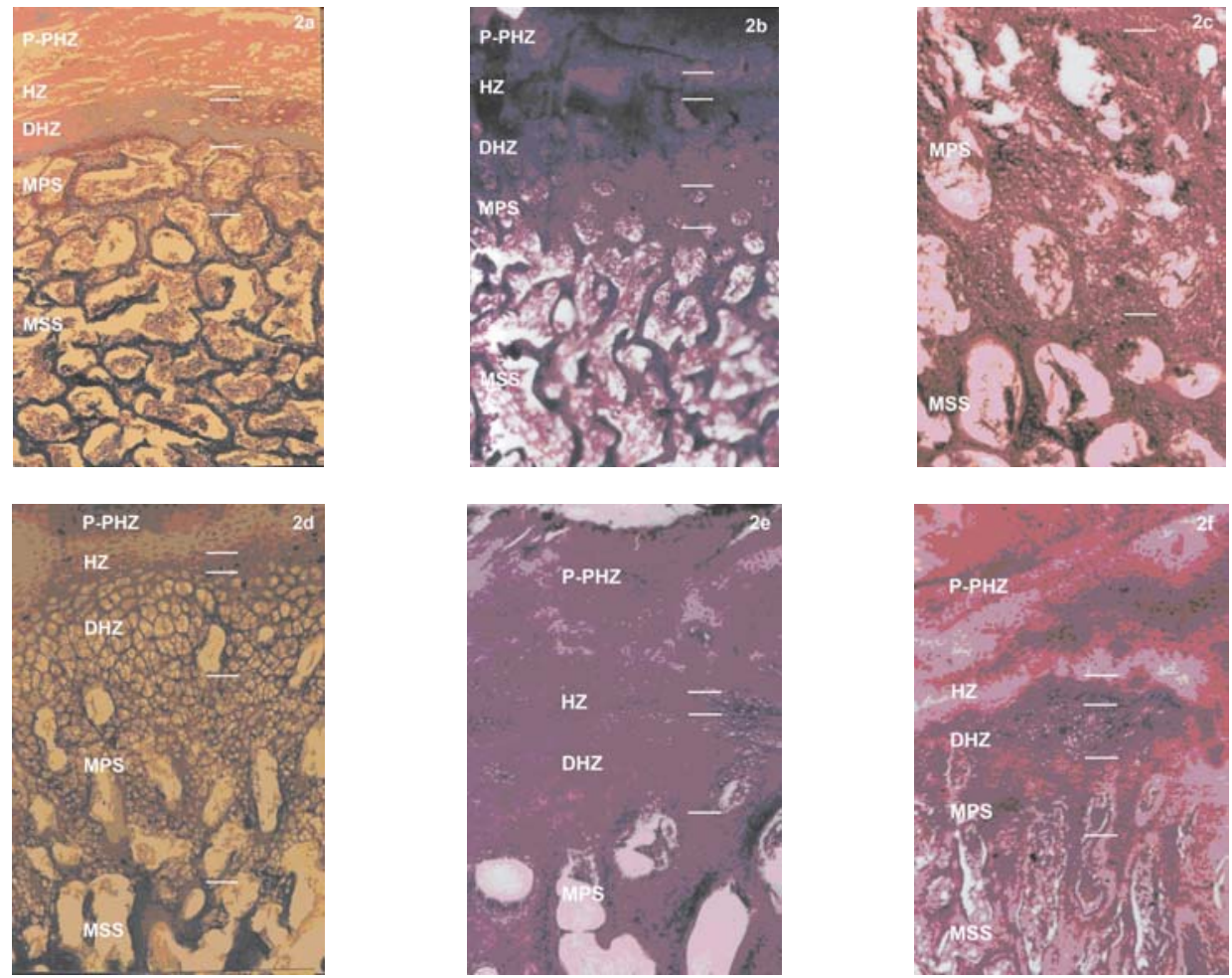

Fig. 2a-f. Microphotographs of proximal part of tibia of 42 days old broilers. H\&E 100x $\mathrm{P}-\mathrm{PHZ}$ - proliferating-prehypertrophied zone, $\mathrm{HZ}$ - hypertrophied zone, DHZ degenerating hypertrophied zone, MPS - metaphyseal primary spongiosa, MSS metaphyseal secondary spongiosa

2a-b) C and C+ group, revealed normal histological morphology, 2c-d) E-I and E-I+ group, note lengthened MPS and shortened MSS, 2e-f) E-II and E-II+ group, there is a shortening of MPS and MSS 
The results suggest that phytase can improve growth performance and phosphorus availability of broilers fed with low phosphorus diets. This is in agreement with the results of the experiment carried out on broilers aged 0-21 days (Živkov-Baloš et al., 2008). Reduction of dietary TP and AP level in experimental broilers resulted in lower body mass and daily gain. However, by introducing phytase into diets negative effects of $P$ reduction were, to some extent, alleviated. Supplementation of phytase in diets lacking mineral source of phosphorus could not prevent significant changes in bone composition and mineralization impairments. Histological, physical and chemical analysis of broiler tibia indicates that the extent and significance of changes depend on $P$ concentration in a diet, as well on phytase addition. Phytase efficacy was greater in diets with reduced level of dicalcium phosphate.

\section{ACKNOWLEDGMENTS}

This investigation was financially supported by The Ministry of Science and Techological Development, Republic of Serbia, Project "Research on pharmacological characteristics of antimicrobial agents, introduction of new technological solutions and alternative prophylactic methods with the purpose to improve control of infectious animal disease", No.TR 031071

Address for correspondence:

Dr. Milica Živkov-Baloš, Research Associate

Scientific Veterinary Institute "Novi Sad"

Rumenački put 20

Novi Sad, R. Serbia

E-mail: milica@niv.ns.ac.yu

\section{REFERENCES}

1. Ahmad T, Rasool S, Sarwar M, Ahsan-ul Haq Zia-ul Hasan, 2000, Effect of microbial phytase produced from a fungus Aspergillus niger on bioavailability of phosphorus and calcium in broiler chickens. Animal Feed Sci Technol, 83, 2, 103-14.

2. Arbor Acres Farm, Inc., 1997, Broiler, feeding and management, Glastonbury, USA.

3. Cabahug S, Ravindran V, Selle PH, Bryden WL, 1999, Response of broiler chickens to microbial phytase supplementation as influenced by dietary phytic acid and non-phytate phosphorus content. I. Effects on bird performance and toe ash, Br Poult Sci., 40, 5, 660-6.

4. Denbow DM, Ravindran V, Kornegay ET, Yi Z, Hulet RM, 1995, Improving phosphorus availability in soybean meal for broilers by supplemental phytase, Poult Sci, 74, 11, 1831-42.

5. Denbow DM, Grabau EA, Lacy GH, Kornegay, ET, Russel DR, 1998, Soybeans transformed with a fungal phytase gene improve phosphorus availability for broilers. Poult Sci, 77, 6, 878-81.

6. Dukes HH, 1975, Djuksova fiziologija domaćih životinja. Svjetlost, Sarajevo, 669-745.

7. Edens FW, Parkhurst CR, Havenstein GB, 1999, Allzyme phytase reduces phosphorus and nitrogen excretion by caged broilers and by broilers in conventional housing, Biotechnology in the Feed Industry, Proceedings of Alltech's 15th Annual Symposium, Edited by T.P. Lyions and K.A. Jacques, Nottingham University Press, Nottingham, U.K., 491-509.

8. Edwards $H M, 1993$, Dietary 1,25-Dihidroxycholecalciferol supplementation increases natural phytate phosphorus utilization in chickens, $J$ Nutrit, 123, 3, 567-77.

9. Ewing ML, Hewat WW, Gilbert RW, Sander JE, Brown TP, 1995, Effect of calcium/phosphorus imbalance in the ration on flock performance in two broiler flocks in North Georgia, Avian Dis, $39,179-82$. 
10. Farell DJ, Martin E, Dupreez JJ, Bongarts M, Betts M, Sudaman A., Thomson E, 1993, The benefitial effects of a microbial feed phytase in diets of broiler chickens and ducklings, J Anim Phisiol Nutrit, 69, 5, 278-83.

11. Haug W, Lantzsch HJ, 1983, Sensitive method for the rapid determination of phytate in cereals and cereal products, J Sci Food Agric, 34, 1423-6.

12. Harland BF, Moris ER, 1995, Phytate: A good or a bad food component, Nutrition Res, 15, 733-54.

13. Harter-Dennis $J, 2000$, Phytase application variations in broiler diets and legislative update. Biotechnology in the Feed Industr, Proceedings of Alltech's 16th Annual Simposium, Edited by T.P. Lyions and K.A. Jacques, Nottingham University Press, Nottingham, UK, 163-74.

14. Harter-Dennis J, Timmons J, Driver J, 2001, Effect of application variation and side activities on the efficacy of phytase in broiler diets. Science and Technology in the Feed Industry. Proceedings of Alltech's 17th Annual Simposium, Nottingham University Press, Nottingham, UK, 242-53.

15. Huyghebaert G, 1997, Effect of microbial phytases on phosphorus utilization. Procedings 11th European Symposium on Poultry Nutrition, Faaborg, Denmark, 24-28. august, 220-35.

16. Jande SS, Dickson IR, 1980, Comparative histological study of the effects of high calcium diet and vitamin D supplements on epiphyseal plates of vitamin D-deficient chicks, Acta Anat, 108, 4638.

17. Jiang S, Jiang Z, Zhou G, Chen Z, Li D, 2009, Non-phytate phosphorus requirements and efficacy of a genetically engineered yeast phytase in male lignana yellow broilers from 1 to 21 days of age, Anim Physiol Anim Nutrit, DOI: 10.1111/j.1439-0396.2009.00981.

18. Jongbloed AW, Kemme PA, Mroz Z, Van Diepen HM, 2000, Efficacy, use and application of microbial phytase in pig production: a review. In: Biotechnology in the feed industry. Proceedings of Alltech's 16th annual Simposium, Nothingam University Press, Nottingham, UK, 111-29.

19. Kornegay, ET, 1999, Feeding to reduce nutrient excretion: Effects of phytase on phosphorus and other nutrients, Biotechnology in the Feed Industry, Proceedings of Alltech's 15th Annual Symposium, U.S.A., Edited by T.P. Lyons and K.A. Jacques, 461-89.

20. Kuznetsov SG, Bataeva AP, Pustovol VV, 1987, Interrelation among calcium, phosphorus and magnesium metabolism in young pigs. Byullten Vssesoyuznogo Nauchnoissledo- vatekiskogo instituta Fiziologii, Biokhimii i Pytania Selskohozyaistvennykh, 1/85, 7-12.

21. Lacey $D L$, Huffer WE, 1982, Studies on the pathogenesis of avian rickets: I Changes in epiphyseal and metaphyseal vessels in hypocalcemic and hypophopshatemic rickets, Am J Pathol, 109, 288-301.

22. Long PH, Lee SR, Rowland GN, Briton W, 1984, Experimental rickets in broilers. Gross, Microscopic and Radiographic Lesions: I Phosphorus deficiency and calcium excess, Avian Dis, 28, 2, 46074.

23. Lukić $M$, 2001, Uticaj fitaze u ishrani brojlera na proizvodne rezultate i zdravstveno stanje, Magistarska teza, Katedra za ishranu, Fakultet veterinarske medicine, Beograd.

24. Maenz DD, Classen HL, 1998, Phytase activity in the small intestinal brush border membrane of the chickens, Poult Sci, 77, 557-63.

25. Mašić B, Antonijević N, Vitorović D, Pavlovski Z, Milošević N, Jastšenjski S, 1985, Prilog određivanju čvrstoće kostiju pilića, Peradarstvo, 8-9, 19-24.

26. Mulyantini NGA, Kumar A, Sands J, Bryden WL, 2004, The efficacy of phytase in corn soybean meal based broiler diets. Asia Pacific J Clin Nutrit, 13, S91-S91, 1/3 p.

27. National Research Council, 1994, Nutrient requirements of poultry, Ninth revised edition, National Academy Press, Washington D.C.

28. Nelson TS, 1967, The utilization of phytate phosphorus by poultry - a review. Poult. Sci, 46, 862-71.

29. Nelson TS, Shieh TR, Wozdinski RJ, Ware JH, 1968, The availabilitiy of phytate phosphorus in soybeen meal before and after treatment with a mold phytase. Poult Sci, 47, 1842-8.

30. Pillai PB, O'Connor-Dennie, Owens CM, Emmert JL, 2006, Efficacy of an Escherichia coli Phytase in Broilers Fed Adequate or Reduced Phosphorus Diets and Its Effect on Carcass Characteristics, Poult Sci, 85, 1737-45.

31. Pravilnik o metodama uzimanja uzoraka i metodama fizičkih, hemijskih i mikrobioloških analiza stočne hrane, 1987, SI. List SFRJ, broj 15. 
32. Qian H, Veit HP, Kornegay ET, Ravindran V, Denbow DM, 1996, Effects of supplemental phytase and phosphorus on histological and other tibial bone characteristics and performances of broilers fed semi-purified diets, Poult Sci, 75, 5, 618-26.

33. Rama Rao SV, Ramasubba Reddy V, Ravindra Reddy V, 1999, Non-phytin phosphorus requirements of commercial broilers and White Leghorn layers, Anim Feed Sci Technol, 80, 1-10.

34. Ravindran V, Wu YB, Thomas DV, Camden BJ, Morel PCH, Hendriks WH, 2001, Improving phosphorus availability in broiler diets based on wheat-soybean meal using microbial phytase produced in solid state fermentation. Science and technology in the Feed Industry. Proceedings of Alltech's 17th Annual Simposium, Nottingham University Press, Nottingham, UK, 255-67.

35. Richter G, 1993, Use of microbial phytase at different phosphorus supply levels in broiler fattening.1. Effect on fattening performance and tibia stability, Arch Tierenahr, 45, 3, 235-44.

36. Schwarz G, Hoppe PP, 1992, Phytase enzyme to curb pollution from pigs and poultry, Feed Magaz, 1, 22-6.

37. Simons PCM, Versteegh HAJ, Jongbloed AW, Kemme PA, Slump P, Bos KD, Wolters MGE, Beudeker $R F$, Verschoor GJ, 1990, Improvement of phosphorus avilability by microbial phytase in broilers and pigs. Brit $J$ Nutrit, 64, 525-40.

38. Simons PCM, Versteegh HAJ, 1993, Role of Phytases in poultry nutrition. Enzymes in animal nutrition, Proceedings of the 1st Symposium Kartause Ittingen, Switzerland 181-6.

39. Scheuer PJ, Chalk BT, 1988, Clinical tests: Histopathology. Wolfe Medical Publications, London.

40. Shakouri MD, Iji PA, Mikkelsen LL, Cowieson AJ, 2009: Intestinal function and gut microflora of broiler chickens as influenced by cereal grains and microbial enzyme supplementatiton, J Anim Physiol Anim Nutrit, 93, 647-58.

41. SRPS EN ISO 6869, 2008, Određivanje sadržaja $\mathrm{Ca}, \mathrm{Cu}, \mathrm{Fe}, \mathrm{Mg}, \mathrm{Mn}, \mathrm{K}, \mathrm{Na}, \mathrm{Zn}$ - Metoda AAS Metoda atomske apsorpcije; SZS, Beograd.

42. Timmons JR, Angel R, Harter-Dennis JM, Saylor WW, Ward NE, 2008, Evaluation of Heat-Stable Phytases in Pelleted Diets Fed to Broilers from Day Zero to Thitry-Five During the Summer Months, J Appl Poult Res, 17, 482-9.

43. Toor GS, Haggard BE, 2009. Phosphorus and trace metal dynamics in soils amended with poultry litter and granulates, Soil Use Man, 25, 409-18.

44. Yi Z, Kornagay ET, Denbow DM, 1996, Supplemental microbial phytase improves zinc utilization in broilers, Poult Sci, 75, 540-6.

45. Van der Klis, JD, Versteegh, HAJ, Simons, PCM., Kies, AK, 1997, The eficacy of phytase in cornsoybean diets for laying hens, Poult Sci, 76, 1535-42.

46. Venäläinen E, Valaja J, Jalva T, 2006, Effects of dietry matbolisable energy, calcium and phosphorus on bone mineralisation, leg weakness and performance of broiler chickens, Brit Poult Sci, 47, 301-10.

47. Vogt $H, 1992$, Effect of suplemental phytase to broiler rations different in phosphorus content. Archiv fur geflugel, 56, 5, 222-6.

48. Vohra A, Rastogi SK, Satyanarayana T, 2006, Amelioration in growth and phosphorus assimilation of poultry birds using cell-bound phytase of Pichia anomala, World J Microbiol Biotechnol, 22, 553-8.

49. Wise $D R, 1975$, Skeletal abnormalities in table poultry, Avian Pathol, 4, 1-10.

50. Živkov-Baloš M, Mihaljev Ž, Kovačević M, Lević J, Gledić D, 2008, The effectivness of microbial phytase on performance and bone tissue characteristics of broilers, Acta Veterinaria, 58, 5-6, 543-54. 
Acta Veterinaria (Beograd), Vol. 62, No. 2-3, 297-311, 2012.

Živković-Baloš Milica et al.: The effectiveness of phytase in broiler

diets in improving production performances and bone features

\title{
EFIKASNOST FITAZE U SMEŠAMA ZA BROJLERE U POBOLJŠANJU PROIZVODNIH PERFORMANSI I KARAKTERISTIKA KOSTIJU
}

\author{
ŽIVKOV-BALOŠ MILICA, KOVAČEVIĆ MIRA, MIHALJEV Ž, STOJANOV I, KAPETANOV M, \\ STOJANOVIĆ DRAGICA i PETROVIĆ JELENA
}

\section{SADRŽAJ}

Izučavane su mogućnosti korišćenja fitaze mikrobijalnog porekla u smešama za brojlere od 21-42. dana, na bazi kukuruza i sojine sačme, sa različitim količinama ukupnog i iskoristivog fosfora. Ogled koji je trajao 22 dana, izveden je na 240 brojlera Arbor Acres provenijence, oba pola, podeljenih u šest jednakih grupa. Brojleri su hranjeni smešama u kojima je količina iskoristivog fosfora bila formulisana na $0,43 \%, 0,23 \%$ i $0,10 \%$, sa ili bez dodatka fitaze. Tokom ogleda praćeni su proizvodni rezultati, zdravstveno stanje i mortalitet, fizičko-hemijske osobine i morfološke karakteristike tibije brojlera. Smanjivanje sadržaja ukupnog $i$ iskoristivog fosfora u obrocima oglednih grupa izazvalo je posledično niže telesne mase i slabije priraste, a dodatak fitaze oglednim smešama je ublažio negativne efekte redukcije fosfora. Histološke, fizičke i hemijske analize tibije brojlera ukazuju na to, da stepen i značajnost promena na kostima zavisi od nivoa fosfora u obroku, kao i prisustva fitaze. Efikasnost fitaze bila je veća u kod ishrane brojlera smešama sa nižim učešćem dikalcijum fosfata. 